disadvantages inseparable from the mountainous character of the country. In Japan and China we know that persevering care and energy have overcome similar disadvantages, but it is not so in Korea. The terrace cultivation, the irrigation works, and above all the patient, almost fastidious labour, which make the hills of Japan and South China yield their share of the earth's good fruits, are practically unknown. Where water is abundant and easily manageable, the lower reaches of the valleys are taken up with rice, the higher portions with millet, beans, buckwheat, \&c. A particularly favourable slope, all the better if it faces the south, is usually as much as the sides of the valley are called upon to contribute to cultivation. There is considerable waste about the paths and paddy-dykes, weeds are rank and numerous, and the prim neatness so conspicuous in Japanese farming is entirely wanting. Much of the newly broken ground is naturally stony, and little effort is exercised to make it less so. However, considering the small amount of labour expended on agricultural operations, the crops are good, and speak eloquently for the fertility of the soil."

Mr. Campbell reached the River Yalu in October, and although he made every endeavour to reach his goal, the snow was so deep, the passes so overhung with accumulations of snow, and his guides so terrified, that he was compelled to turn back when within a mile or two of the summit. Nevertheless, he succeeded in making observations of considerable interest.

" Peik-tu San, or Lao-pai Shan (Old White Mountain) as it is at present called by the Chinese of Manchuria, is the most remarkable mountain, naturally and historically, in this part of Asia. The perennial whiteness of its crest, now known to be caused by pumice when not by snow, made the peoples that beheld it from the plains of Manchuria give it names whose meanings have survived in the Chinese Ch'ang-pai Shan, or Ever White Mountain. This designation, obviously assigned to the White Mountain alone, has been extended to the whole range without apparent reason, for no other peak of it, so far as is known, can pretend to perpetual whiteness, whether of pumice or snow. Some 100 miles south-east of Peik-tu San there is a Ch'ang-perk San (Ever White Mountain) which must approach, if it does not exceed, the White Mountain in height, but tbe Koreans do not credit it with a snowy covering for more than nine months of the year, and a European traveller who has seen it informs me that it is wooded to the summit, quite unlike Peiktu San, which is bare of forest for the last 1000 feet of its height, The great point of interest in the mountain, apart from its whiteness, is the lake- 12 miles in circuit according to $\mathrm{Mr}$. James and his party, the only Europeans who have seen itwhich lies in the broad top of the mountain at a height of 7500 feet above sea-level, and is supposed to be the source of the three rivers, Yalu, Tumen, and Sungari. The $T e i T_{e} i-k i$, Great Lake, as the Koreans call it, is the nucleus of a mass of legend and fable. It is a sacred spot, the abode of beings supernstural, and not to be profaned by mortal eye wilh impunity. Curiously enough, neither Chinese nor Koreans have the faintest notıon of the real character of Peik-tu San. The Chinese say that the lake is an 'eye of the sea,' and the Koreans tell you that the rock of which the mountain is composed floats in water, for lumps of pumice were common on the Yalu at Hyei-san." Mr. Campbell's crude geological explanations, that this cho.san (ancestral mountain) of Korea was a burnt-out volcano, whose crater had been filled with water by springs, were listened to with polite wonder, and treated with much less credulity than they deserved. He pointed to the black dust, to the clinkers, and to the rocks lining the banks of the Yalu for miles, many of which looked as if they had been freshly ejected from some subterranean furnace, bnt to no purpose. If the occurrences he spoke of had taken place, they must have been handed down by tradition; and it was useless to cite lapse of time-Koreans are ignorant of geological periods-to people whose history extends as far back as 4000 years ago. According to Mr. Campbell's observation, most of the forest between Po-ch'ön and Peik-tu San grows on volcanic matter, which was without doubt ejected from Peik-tu San during successive eruptions. The general inferiority of the timber hereabouts to that which he saw elsewhere in Korea led him to examine the soil wherever an uprooted tree or a freshly-dug deer-pit furnished the opportunity. " Beyond a thin coating of leaf-mould on the surface, there was seldom anything else but pumice, broken to the size of a very coarse sand. According to the hunters, this was the subsoil everywhere in the forest, and to my knowledge it extends for forty miles at least to the south from Peik-tu San.
Nearing the mountain we get the clearest evidence of the character and recency, geologically speaking, of the eruptions which spread this vast quantity of volcanic material over such a wide area. Ten miles due south of the White Mountain, the Yalu, now 8 or to yards broad and very shallow, flows between banks like a railway-cutting, sheer, clean, and absolutely devoid of vegetation, for denudation was too rapid to permit the slightest growth." The sections thus exposed were often over 100 feet in depth, and at one of the deepest portions Mr. Campbell counted thirteen layers of black volcanic dust, all varying in thickness, and each separated from the layer above by a thin layer of light-coloured mould. So fine was this dust that the least breath of wind caught it and scattered it freely over the adjoining snow, to which it gave a grimy, sooty appearance.

"The forests of South Manchuria, though uninhabited now, were, we learn from Chinese records, the home of many races in ages past. The comparatively recent kingdom of $\mathrm{Ko} \cdot \mathrm{kn}$-rye, which arose in the first century B.C., is said to have occupied the Ch'ang-pai Shan and the head-waters of the Yalu river. Anyone who has travelled through the forests might be inclined to doubt such records, for, excepting hunters' lodges, one never notices a vestige of human occupation. Hut it must be remembered, on the other hand, that the word kuk (Chinese kuo), country or kingdom, was applied in the early history of Korea and Manchuria to very limited communities, often to mere villages. The word "tribe" better expresses what the so-called kingdoms actually were; and when we bear in mind their low civilization and the impermanent character of their dwellings, it is not surprising that my hasty journey failed to throw any light on the ancient inhabitants of these forests." Since his return, however, Mr. Campbell was informed by Mr. Fulford that Chinese hunters told him of the discovery by them of human implements-of what kind Mr. Campbell cannot say-when digging deer-pits near the White Mountain.

Mr. James, in a paper read before tha Royal Geographical Society in June 1887 , described very fully the guild of hunters which practically owns and rules the forests to the north and west of Peik-ta San. The Koreans have no such guild, probabiy because they have not so much to fear from bandits, but each hunter has a recognized right of ownership over a rudely defined district in the neighbourhood of his hut. Over this he hunts and traps deer in summer, and sable at the begining of winter, altogether spending about tive months of the year in the forest ; the remaining seven are passed at his home on or near the Yalu, either tilling his ground or living in idleness on the proceeds of hunting seasons. Besides sable and deer, tiger leopard, bear, pig, and ermine are found here ; bear, probably the common brown species (Ursus artes), are said by the hunters to be very numerous in summer. In mid-Korea $\mathrm{Mr}$. Campbell has seen a small black hear with a white patch on his chest (Ursus tibetanus), but the Yalu trappers did not seem to know it. Hazel-grouse were the only game-birds he noticed. Throughout the forests insect pests abound in the summer months. Mosquitoes, gnats, and gad-flies make the lives of the settlers perfectly burdensome for two or three months of the year, and ponies and bulls quickly succumb to their attacks. The houses are kept constantly filled with birch-smoke to drive them off; cattle are protected hy fires of greenwood in the open; and men working the clearings carry coils of rope made from dried Artemisia, which burns slowly and temits a pungent odour, for the same purpose.

\section{THE GEOLOGY OF THE HIMALAYAS}

THE twenty-third volume of the Memoirs of the Geological Survey of India, consisting of some 250 pages, is wholly taken up by an account of the geology of the Central Himálayas, by the Superintendent of the Survey, Mr. C. L. Griesbach, C.I.E. The carefully written text is illustrated by some of the most exquisite and instructive photographs of synclinals, folded beds, faulıs, glaciers, \&c., which have ever been produced, to say nothing of the numerous maps and sections.

We have thought it best to give Mr. Griesbach's conclusions on the important subject with which he deals in his own words :-

The Himálayan region forms part of the vast structure of the Central Asian elevation; it is so closely connected with the latter, both structurally and geographically, that it is very

NO. 1 I 6 I, VOJ. 45] 
difficult to decide its exact limits. Native geographers and the Puranic scriptures define the Himálayas as comprising only the chain of snowy peoks at the head of the Ganges drainage. Modern views generally limit the Himálayas to the system of mountain ranges which extend between the Brahmaputra and Indus rivers. Of course, structurally, these ranges continue beyond these bounciaries, but there are distinct changes in the features of the ranges which make these limits advisable. As regards the lateral extension of the region, several views have been formed; but $I$ consider it most convenient, and at the same time more in accordance with the original significance of the term, to call Himálayas only the system of ranges which fringe the Tibetan highlands along its southern margin, a view which is now most generally held. That part of the system in which rise the headwaters of the Ganges drainage, and extending north-westwards as far as the Sutlej gorge, I call here the Central Himálayas, and within this area I divide the Central ranges into ( $\mathrm{r}$ ) Northern range (watershed), and (2) Southern range (line of highest peaks).

Whilst the Southern range of the Central Himálayas is formed chiefly of crystalline rocks, mostly gneissic with metamorphic schists, it is shown that the Northern range is almost entirely composed of a vast sequence of sedimentary strata, ranging from the lowest palæozoic to tertiary and recent age. The detailed description of these various formations I have given in the preceding pages, and I will here only recapitulate the following points.

Immediately on the crystalline schists reposes an enormous thickness of beds of varying lithological character, named haimantas by me, which are sharply defined near its upper limit by most characteristic red quartz shales, which form the base of the richly fossiliferous lower silurians. Structurally, this system is very much more fully developed than the succeeding silurians, being in most sections more than double the thickness of the latter. But the lower limit of the haimantas is obscure; an almost perfect lithological passage may be traced from the crystallines (vaikritas) into this system, both in the western and easternmost sections ilescribed.

One of the most characteristic amongst the various horizons in this system is a great thickness of a coarse conglomerate or boulder-bed, which in some sections alternates with slaty beds, but is never entirely absent. This, in conjunction with the ripple-marking which may be seen on nearly all the slaty beds of the haimantas, indicates clearly that we must suppose the ancient coast-limits of haimanta age to have been in close proximity. The apparent overlap of haimantas on gneiss (Niti area) is easily explained, if we suppose this system to have been developed in this region as a littoral formation. It is extremely probable that one of the earliest Himálayan disturbances occurred inımediately before haimanta times.

Lithological resemblance, not less than structural features, point to the probability that a part at least of the slate series of the Lower Himálayas are equivalents of the haimanta system of the Central Himálayss. I believe even that some of the older rocks, which immediately underlie the Vindhian group, may yet be found to belong to the same age. It would thus follow that the haimanta seas had extended not only over the greater part of the present Himálayan area, but perhaps also as far south as Central India. If so, the line of the Central Himálayas was probably marked out as a chain of elevations, from the waste of which the boulders and pebbles of the haimanta conglomerate and of the Simla roclss were derived. The latter supposition is also advanced by the authors of the "Manual."

The palæozoic group forms an uninterrupted sequence from the lowest haimantas to the upper carboniferous; and this sequence is the same, or nearly so, in all the sections of the Central Himálayas. The first indications of a disturbance are noticeable in the upper carboniferous. Certain beds of the Iatter are wanting in some sections, and I found the next following system overlapping what I must look upon as an eroded surface of upper carboniferous.

Nearly everywhere I found the latter overlaid by a great sequence of beds, which represent permian, trias, rhætic, and lias. This group of systems forms an uninterrupted sequence, with conformable bedding throughout. The base of the sequence is everywhere seen to be dark crumbling shales, which contain a palæozoic fauna, probably permian in character, which.gradually passes into lowest trias beds through dark limestones and shales which have yielded a curious fauna, some of the species of which have strong affinities with permian forms. On it rest

$$
\text { r Page } 679 \text {. }
$$

lower trias beds, followed by a continuous succession of strata, which reach up into the lower lias.

The same condition prevails in Spiti, where the lower lias is also well represented.

The lias limestones and shales are overlaid by jurassic (Spiti) beds, which have yielded a large number of fossils, but which have not yet been entirely examined. Most of them appear to belong to the upper jurassics rather than middle or lower. Whether the latter is represented or not, is not quite clear, but the bedding of the Spiti shales is isoclinal with the lower lias, and if there is an unconformity between these systems, it may only be conjectured from the sudden and entire change in lithological character of the two formations, coupled with the absence of lower jurassic forms amongst the species found in the Spiti shales.

From this formation there is a gradual passage into the greenish shales and sandstones of the cretaceous (with perhaps upper jurassic), the Gieumal sandstone of Stoliczka. Again a sudden change in lithological character from these sandstones into the white limestone of the upper cretaceous seems to point to the probability of there having occurred physical changes on a large scale after the deposition of the lower cretaceous. In the Central Asian area, and also in the Perso-Áfghán region, a strongly marked overlap of the upper cretaceous over the neocomian limestones may be observed.

Probably similar features will be found to exist in the Himálayan area, the cretaceous rocks of which have not been closely studied.

The tertiary system is fully developed, though few fossils were found in it. A great unconformity occurs between certain sandstones which cannot be older than upper eocene (overlying nummulitics), and are probably of miocene age, and horizontal beds of clay, sand, gravels, and sandstone, which form the high table-land of Húndés, which, having yielded mammalian bone remains, are commonly known as the ossiferous beds of Húndés.

From the foregoing it will be seen that special disturbances must have occurred in early geological times, and have been repeated periodically.

It is very certain that near the beginning of the haimanta era sufficient physical changes have occurred not only to completely alter the lithological character of the deposits in course of formation, but also the area in which the latter were laid down. The great thicknesses of coarse conglomerates, which are of widespread extent in the lower haimantas, indicate the nearness of land at the time, or, as I may term it, the existence of an early region of elevation in place of the present area of the Central Himálayas. At the same time litbological, not less than structural, conditions point to the probability of true haimanta deposits having been laid down also on the south slope of what is now the Central Himálayan region.

The compression of the Himálayan, and indeed entire Central Asian area, and consequent folding, and thus elevating of it, most probably went on uninterruptedly and continuously from the earliest epochs to the present; indeed, the natural forces exerted on the surface of our globe condition this. But in addition to this, periodical greater changes have taken place, and are proved by the sections of the Central Himálayas.

After the lower haimanta recession of deposits from the entire Himálayan area into well-defined northern and southern regions of formations, we find an undisturbed sequence of beds till the upper carboniferous, when clear evidences of a great overlap may be observed. This is well marked in the Central Himálayas, and is clearly proved in the Perso-Áfghán area, where carboniferous marine limestones are followed by littoral deposits, the upper beds of which contain a triassic fauna. Here we have therefore a period of sub-aërial and marine erosion of the carboniferous, followed by an overlap of probably a permian and triassic sequence of deposits.

The third period of disturbance seems to belong to the lower jurassic age, where a gap (partial or otherwise) between lower lias and middle or upper jurassics is probable.

I may mention that this gap is not observable in the PersoAfghán region, where the passage from the trias into jurassics and neocomian is gradual.

On the other hand, a decided overlap on an immense scale has occurred in later crelaceous times in Central Asia, and we find that hippuritic limestone covers both jurassics and neocomian unconformably. Such is less apparent in the Central Himálayas, though probable enough when considering the sudden change from the sandstone and shales of the lower cretaceous to the hard white and grey limestone of the upper cretaceous.

The fifth period of disturbance, which is clearly shown in the 
Central Himálayas, occurred after the deposition of the sandstones which overlie the nummulitics of Húndés, and which are probably of miocene age. A considerable gap seems to exist between the latter and the ossiferous younger tertiaries which fill the Húndés basin.

There is clear evidence, therefore, of very early disturbances having taken place in the Himálayan area. There are abundant proofs that minor changes in the distribution of land and water have occurred not only frequently, but we can scarcely believe otherwise than that the forces which have resulted in the intricate folding and crumpling of the great sequence of sedimentary and crystalline strata must have been of very long duration, and were probably existent from the very earliest date when the first grain of sediment was deposited in the Himálayan seas. We can go further. Whatever other-and as yet only dimly understoodforces were at work to produce this contraction and folding of the earth's crust, we know of two forces about which there can scarcely be the slightest doubt. The first is the gradual cooling of our earth, and consequent lessening and shrinking of the surface of it. Secondly-and this is a force which may be mathematically expressed-we know that the centrifugal force endeavours to move every point on the surface of the earth in a direction opposite to that in which gravitation attracts it.

The actual force exerted is the resultant between the centrifugal and tangential forces, and it has the tendency, if I may so express it, of gradually moving each point on the surface of the earth towards the equator. It may be supposed that an enormons sequence, of to a certain extent pliable deposits, trying to move bodily, as it were, towards the equator, but en route arrested and banked up against a rigid mass of which the peninsula of India is a small remnant only, must necessarily have suffered wrinkling, and lateral crushing.

These forces operated since the earth existed, and must be active now. But throughout the great sequence of the palæozoic, mesozoic, and kainozoic deposits, we search in vain for an internal explanation of the great unconformities and disturbances of coast-line which have taken place at certain intervals, such as I have sketched out above. That these changes were not local overlaps only is apparent when we compare the Central Himálayan area with the Perso-Afghán region. In the latter the physical changes are far more clearly marked. At the close of the carboniferous epoch, which was one of pelagic conditions in the Hindu Kúsh area, Khorassán and Persia, the distribution of land and water must have considerably changed, as we find immediately above the carboniferous limestone, shaly beds with coal-seams, and conglomerates and partly littoral, partly freshwater conditions prevailed in that area till late into jurassic times. These disturbances, which are slightly indicated in the Himálayas, are clearly shown and occur on a larger scale in the West Central Asian area.

The next great change in the Perso-Afghan area is the great overlap of the upper cretaceous (hippuritic) limestone over the neocomian, already alluded to. It has resulted in a great and often strongly expressed unconformity. Again, another and strongly marked change occurs in the middle tertiaries of the Perso Afghán area. The purely marine miocene beds are overlaid, often with isoclinal bedding, at other localities distinctly unconformably, by upper tertiary freshwater deposits. If the folding and crushing process were alone the cause of theseshall I call them cycles of disturbances-then at least some evidence of it should be observable within the sequences of rocks as we see them.

On the other hand, there is no direct evidence to show that the raising of the Himálayas as a mountain system was in any way due to these periodical fluctuations of sea-level, or, as Suess terims it, the "positive" and "negative" movements of the liquid covering of the earth. The evidence of the transverse valleys in the Himálayas points even to the probability that the rajsing up of the chains of hills forming them, i.e. the folding and crumpling of its rock strata, must have kept pace, step by step, with the erosion by rivers which we now find traversing the whole width of this mountain system.

Such transverse valleys, however, can only date since the last of the periodical changes spoken of, i.e. since the middle tertiary epoch. Before that time, up to the point when the last marine tertiary deposits were laid down along the margin of the Himálayas, the relative position of Peninsular India and Central Asia must have been the reverse of what we know them to be now ; that is to say, the surface of the Central Asian elevated massif must have been nearer the centre of our earth than the surface of the continent, of which the Peninsula gof India forms only a portion of the remains.

It is improbable that the folding action alone has been the cause of the present structure and orographical features of Central Asia and the areas south of it: for the final great changes which have resulted in the draining of Central Asia of the tertiary seas, of which nothing now remains but isolated saltwater lake-basins, such as the Aral and the Caspian are, we must look for other causes.

Possibly such may be found in the sinking in of large portions of the southern hemisphere which caused the submergence of the Indo-African area below what is now the Indian Ocean. With it the part now known to us as the Peninsula of India may have partially broken down, though of that we have no direct evidence, unless the improbability that the Central Asian area could have been pushed up to its present elevation above the Peninsula entirely through being folded might be adduced as proof. Large tracts of Central Asia we know could never have suffered folding to any but very slight extent, as, for instance, the greater part of the tertiaries of the Turkistán region which are often in undisturbed horizontal position. On the other hand, these latter are but little raised above-some are even depressed below-the level of India.

In all these considerations and speculations two points seem probable almost beyond doubt, namely: First, that the last and main disturbance of physical conditions of the Central Asian area has taken place in post eocene, perhaps in middle tertiary times, and is most likely still continued to the present day. ${ }^{1}$ Secondly, that this period of disturbance coincides with the sinking in of the Indo-African continent, which "breaking down" caused the final draining of the tertiary seas from the Central Asian area.

Not so certain is whether the raising en bloc of the Central Asian mass above the level of the Indian Peninsula is due only to the folding process, or whether some movement downwards of the Peninsula, in connection with the sinking in of the IndoAfrican region, may not have had a share in producing the present configuration of the Húndés plateau. Some such movement may be conjectured. Certain supposed elevations of the Peninsula may possibly be cwing to "negative" movements of the area of the Indian Ocean-in other words, to the sinking in of the ocean bed. ${ }^{2}$

\section{SCIENTIFIC SERIAISS.}

American Journal of Science, January.--Theory of an interglacial submergence in England, by G. Frederick Wright. The theory of deep interglacial submergence which has been propounded to account for the shell-beds at Moel Tryfaen, near Snowdon, and at Macclesfield, is opposed by several formidahle objections, viz. (I) the subsidence must have been one which affected North Wales and central England without affecting the region south of the the Thames and Bristo Channel; (2) there is in other places a considerable absence of marks of subsidence over the northern part of the centre of England, where it is supposed to have been the greatest ; (3) the Pennine Chain is not more than 25 or 30 miles wide from east to west, yet east of Macclesfield there is an entire absence upon its flanks both of glacial deposits and of beach lines; (4) the shell beds are strictly confined not only to the area which was demonstrably covered by glacial ice, but to those more limited areas which were reached by ice that is known to bave moved in its way over shallow sea-bottoms; (5) the assemblage of shells is not such as could have occurred in one place in the ordinary course of nature. The anthor develops a system of glaciers which will explain the facts at present known, upon the supposition of a single glacial epoch. - The Permian of Texas, by Ralph S. Tarr. It is shown that the Permian of Texas is, like other areas of Permian, a deposit in large measure made in an inland sea.The chemical composition of iolite, by O. C. Farrington. The formula obtained from two analyses of exceptionally pure specimens of the mineral is $\mathrm{H}_{2} \mathrm{O} \quad 4(\mathrm{MgFe}) \mathrm{O} \quad{ }_{4} \mathrm{Al}_{2} \mathrm{O}_{3} \mathrm{IOSiO}_{2}$, the ratio of $\mathrm{MgO}$ to $\mathrm{FeO}$ in the two cases being as $7: 2$. - On a series of cæsium trihalides, by H. L. Wells; inciuding their crystal lography, by S. L. Penfield. Upon adding bromine to a concentrated solution of cæsium chloride, a bright yellow precipitate was obtained, from which crystals were formed having the composition $\mathrm{Cs} . \mathrm{Cl} . \mathrm{Br}_{2}$. An attempt has been made to

$$
\begin{aligned}
& \text { : "Manual," pp, Jvi., } 680, \& \mathrm{c} \text {. } \\
& \text { "See "Manual," p. 68r. }
\end{aligned}
$$

No. I I 6I, voL. 45] 